\title{
RAPORTUL DINTRE SACRU ȘI PROFAN ÎN ANTROPONIMIA ROMÂNEASCĂ MEDIEVALĂ (SEC. 15-17)
}

\author{
DOMNIȚA TOMESCU \\ Universitatea „Ovidius” Constanța \\ Universitatea Petrol-Gaze, Ploiești, România
}

\section{The relationship between sacred and profane in medieval Romanian anthroponymy $\left(15^{\text {th }}-17^{\text {th }} \mathrm{c}\right.$.}

\begin{abstract}
The paper analyses the sacred and profane components of the medieval inventory of Romanian first names. The series of religious and secular names, established through the registration of their forms in historical sources, reveal the creation of a shared onomastic tradition in Moldavia and Wallachia. The onomastic system is unitary for religious and profane given names, imported from the Slavic language or created in Romanian from autochthonous lexical forms. The stock of historical names is similar in both historical areas. The research focuses on the quantitative differences and varied frequency of the Moldavian and Wallachian forms, motivated by historical and cultural conditions.
\end{abstract}

Keywords: sacred, profane, first name, religious/laic name, frequency.

1. Lucrarea de față își propune să analizeze un aspect esențial al actului denominativ personal: atribuirea unor nume religioase (biblice și calendaristice), reprezentând, din punct de vedere cultural, domeniul sacrului, respectiv, a unor nume laice (împrumuturi sau creații românești), care aparțin domeniului profan. Opoziția terminologică (sacru / profan, religios / laic) sugerează necesitatea raportării celor două tipuri de nume personale, marcate de această antonimie, care alcătuiesc, de altfel, structura de bază a inventarului antroponimic românesc, de la începuturi până în prezent. Cercetarea comparativă privește exclusiv numele primare (nume de botez / prenume), prezența celor două categorii în repertoriul numelor de familie reprezentând oficializarea supranumelor individuale patronimice, matronimice sau maritale, care fixează primele nume personale. $\mathrm{Nu}$ avem în vedere numeroasele hipocoristice și diminutive care diversifică formele onomastice de bază. Analiza se referă la cantitatea și frecvența formelor antroponimice religioase vs. laice, atestate în antroponimia istorică. Distribuția numelor pe marile arii onomastice ale provinciilor românești istorice este semnificativă. Dificultăți de ordin documentar privitoare la Transilvania acestei perioade (absența edițiilor cu text paralel, colecții parțiale, de obicei tematice) explică restrângerea analizei paralele a numelor personale la Moldova și Țara Românească.

Am delimitat perioada de referință (secolele 15-17), având în vedere primele 
două epoci ale dezvoltării sistemului onomastic românesc: formarea sistemului antroponimic medieval (secolele 11-14) și consolidarea sa (secolele 15-17) (Tomescu 2001:77). Perioada analizată se caracterizează prin unitatea și continuitatea numelor de persoană cu antroponimia secolelor de început, atât ca tendințe denominative, cât și ca inventar de forme, dar fondul arhivistic restrâns al perioadei de început atestă puține forme onomastice comparabile după criteriile enunțate.

2. Formarea sistemului antroponimic românesc se relevă ca un proces continuu, iniţiat de timpuriu, care se manifestă deja unitar și specific la începutul secolului 15 , prezentând o structură de bază a inventarului denominativ, alcătuită din nume religioase și nume laice. Se observă că cele două componente ale repertoriului onomastic se opun prin originea formelor, uneori prin intenția denominativă a donatorilor, nu prin uzul lor, ambele tipuri de nume fiind înregistrate în comunitatea creștină, preponderent ortodoxă, mai rar, catolică. În denominația populară românească, numele de botez sau prenumele, de factură religioasă sau profană, se atribuie la naștere și se consfințește prin botezul religios. Conform tradiției românești, numele religioase au valoare devoțională, copilul fiind pus, prin nume, sub protecția unui sfânt din calendarul lunii în care se naște sau se botează copilul, mai ales, dacă data nașterii sau a botezului coincide sau este apropiată de sărbătorirea sfântului ales (Pașca 1936: 24-25). De multe ori, numele creștine se transmit în familie, conform altei vechi tradiții de atribuire a numelor părinţilor, bunicilor, strămoșilor, fără legătură cu data naşterii sau a botezului. Pe aceeași cale se transmit şi numele laice din ascendența familiei. $\mathrm{O}$ altă cale de răspândire, în egală măsură, a numelor creștine, respectiv, laice este obiceiul preluării numelor naşilor de botez (Pașca 1936: 27). Alegerea numelui este liberă, în general, motivația numelui depinzînd de intenția sau de dispoziția donatorului, care poate, de asemenea, atribui un nume străin sau un nume creat. Numele străine, ca și numele create, se propagă prin purtători de notorietate sau de importanță socială, prin imitație sau prin atracția noutății.

\section{Numele primare religioase}

Numele primare românești de factură religioasă (Constantinescu 1968, Bălan Mihailovici 2002) alcătuiesc un inventar onomastic care reunește, după proveniență, mai multe tipuri denominative:

a) numele biblice (forme onomastice ebraice din Vechiul Testament, uneori redate în variantă grecească sau latină, prin traducerea Bibliei), reprezentând:

$a_{1}$ ) nume biblice necalendaristice ${ }^{1}$ :

- nume ale primilor oameni creați de Dumnezeu: Adam < ebr. Adhamah „sol, pământ"; Eva < ebr. Chavva „viață";

- nume ale patriarhilor biblici: Avram < grec. Abráam, lat. Abram < ebr. Abrahám „tatăl este înălțat, mărit”; Aron < ebr. Aaron „iluminat, învățător”

1 Unele dintre aceste nume figurează în calendarul religios, ca nume martirologice, fiind purtate, mai târziu, de persoane sanctificate de biserică pentru sacrificiul lor. 
- nume ale regilor biblici: David < ebr. Dawidh „cel iubit”; Solomon < ebr. Shelomoh „cel paşnic, cel care aduce pacea”;

- nume ale eroilor biblici: Samson < ebr. Shimshon „născut din soare, solar” etc.

$a_{2}$ ) nume biblice calendaristice:

- nume ale profeților biblici, sărbătoriți de biserica (răsăriteană sau apuseană): Ieremia < gr. Ieremiás, lat. Hieremias, < ebr. Yirmeyah „înălțarea Domnului”; Ilie < grec., lat. Elias < ebr. Eliyâhu „Dumnezeul meu este Iehova”; Moise < grec. Moses, Moyses < ebr. Mosheh; Naum < ebr. Naum „cel mângâiat”, Zaharia < grec. Zaharías, lat. Zacharía(s) < ebr. Zekarjah „Iehova și-a amintit”.

b) nume creștine hagiografice calendaristice: reprezentând:

$\mathrm{b}_{1}$ ) nume ebraice din Noul Testament, traduse în limbile greacă și latină:

- numele simbolic al lui Mesia: (E)Manoil < ebr. Immanoil „Dumnezeu este cu noi";

- numele apostolilor lui Iisus Hristos, celebrați ca mari sfinți ai bisericii: Petru < grec. Pétros, lat. Pétrus < traducerea ebr. Kepha „piatră”; Ioan < grec. Ioánnes, lat. Iohánnes, Ioannis < ebr. Iochanan „Dumnezeu este milos”; Iacob < grec. Iacóbos, lat. Jacóbus, Jácobus < ebr. Ya'aqobh "țiitor de călcâi, geamăn”; Matei < grec. Mattháios, lat. Mattheus < ebr. Matithyaâh „darul lui Iehova”; Toma < grec., lat. Thomás, lat. Thómas < ebr. Toam „geamăn”;

- numele arhanghelilor: Gavril < grec. Gabriél, lat. Gábriel < ebr. Gabhriel „eroul lui Dumnezeu”; Mihai (l) < lat. Michael < ebr. Mikha'el „cine-i ca Dumnezeu?”;

- numele sfintelor rude ale lui Iisus: Iosif < grec Ioséph, Iosepos, lat. Ióseph, Ioséppus $<$ ebr. Yoseph „Dumnezeu să adauge”, Maria < grec, lat. Maria < ebr. Miryam, Maryam „amărăciune” sau „cea dorită”, Ioachim < grec. Ioakim(os), lat Ioachim < ebr. Jehojakim, Ana < grec., lat. Anna < ebr. Hannah „îndurare, bunăvoință”, Elisabeta < grec., lat. Elisabeth < Elisheba „Dumnezeu este jurământul”;

$\mathrm{b}_{2}$ ) nume grecești din Noul Testament, adaptate și în variantă latină:

- nume ale apostolilor lui Iisus: Andrei < grec. Andréas < andreia „bărbăție, curaj” $<$ grec. anér, andros „bărbat”, lat. Andréas, Andréa, Filip < grec. Phílippos „iubitor de cai”, lat. Philippus;

$b_{3}$ ) nume grecești de proveniență laică, consacrate de mari personalități ale bisericii, înscriși în rândul celor mai însemnați sfinți ai creștinătății, mai ales, ai tradiției ortodoxe: Vasile < gr. Basileios < grec. basileos „împărat”, lat. Basilius, Dumitru, Dimitrie < grec. Demétrios, Dimitrios < al (zeiței) Demetra, lat. Demetrius, Gheorghe < grec. Geórgios (Gheórghios) < gr. georgós „lucrător al pământului, țăran”, lat. Georgius, Grigor $(i) e<$ grec. Gregórios „,cel care veghează”; Nicolae < grec. Nikólaos (< grec. nikao „a învinge” + laos „popor”), lat. Nicoláus; Ștefan < grec. Stéfanos < „cunună, coroană”; Teodor < grec Teodoros „darul lui Dumnezeu”.

$\mathrm{b}_{4}$ ) nume latinești de proveniență laică, purtate de mari personalități sanctificate: Constantin < lat. Constans, Constantis < lat. constans, constantis "ferm, puternic"; Anton < lat. Antonius, grec. Antónios; Marcu < lat. Marcus „nume dat celor născuți în luna martie”.

c) nume martirologice, transmise de mucenici care s-au jertfit pentru credința creștină: 
- nume grecești de proveniență laică, unele cu variantă latină: Ambrozie < grec. Ambrósios < grec. ambrosia „mir purificator”; lat. Ambrosius; Atanasie < grec. Athanasios < grec athanasia „nemurire”, lat. Atanasius; Cosma < grec. Kósmas < grec. kosmos „ordine, univers, podoabă”; Macarie grec. Makarios „cel fericit”; Cristofor < grec. Hristofóros, grec. Hristos + fóros „purtător de Hristos”; Nichifor < grec. Nikifóros < grec. nike „victorie” + fóros „purtător”, „purtător de victorie”, Pantelimon < grec. Pantéleimon „atotmilostivul” < grec. panta „tot” + éleimon „milos” < éleos „mila””; Irina < grec. Eiréne „pace”, Sofia < grec. Sofía < grec. sofia „înțelepciune” etc.

- nume latinești de proveniență laică: Benedict < lat. Benedictus „binecuvântat”, Roman < lat. Romanus „roman”, Sever, Severin $<$ lat. Severus, Severinus $<$ lat. sever ,aspru, serios, neîduplecat";

d) nume de sărbători religioase:

- nume grecești: Anastasie < grec. Anastásios < grec. anastásis, anastáseos „înviere”, lat. Anastasius; Parascheva < grec Parascheve „pregătire (pentru Ziua Învierii, Vinerea Mare";

- nume latinești: Natalie, Natalia < lat. natalis (dies) „Crăciun”, Pascal, Pascu < lat. Paschalis „pascal, de Paști”

- nume românești: Crăciun, Paștea < Paști.

Numele religioase constituie un fond onomastic general, comun tuturor limbilor creștinătăţii, reprezentând o timpurie manifestare a fenomenului de globalizare culturală. Nucleul acestui sistem de nume creștine este constituit din puține forme, intens circulate, care corespund importanței și semnificației sfinților celebrați prin nume. Răspîndirea numelor primare religioase este reconsolidată de cele mai multe ori de faima unor purtători succesivi, martiri sau personalități ale bisericii.

\subsection{Numele primare religioase masculine}

3.1.1. În secolul 15, în Moldova și Țara Românească, mărturiile documentare (DRHA I 434-510, II 462-533; DRHB I 529-586) arată constituirea unui inventar onomastic românesc, cu un număr redus de forme onomastice religioase, dar cu largă difuziune, destinate denominației bărbătești. Numele din seria denominativă masculină sunt mai frecvent atestate decât cele feminine, fapt explicabil pentru poziția socială a femeii în societatea feudală, dar și pentru specificul mențiunilor documentare care se referă, mai ales, la capul familiei. Circulația formelor onomastice medievale arată consolidarea tradiției de preluare denominativă a numelor sfinților, celebrați de calendarul creștin ortodox. Trebuie să se țină seama că numărul înregistrărilor numelor de persoane din Moldova este mult mai mare, în condițiile existenței unui număr dublu de documente moldovenești pentru aceeași perioadă.

Inventarul numelor primare masculine numără 53 de forme distincte în Moldova, față de 19 forme în Țara Românească. Ierarhia acestor prenume, în ordinea frecvenței mențiunilor documentare pentru persoane diferite ${ }^{2}$ indică următoarele preferințe

2 Numărul mențiunilor documentare va fi notat între paranteze drepte după numele respectiv. 
denominative, în Moldova: Ioan [77], Petru [52], Stefan [32], Mihail [29], Teodor [29], Luca [19], Toma [19], Lazăr [10], Nicolae [9], Alexandru [9], Andrei [9], Manoil [9], Gheorghe [7], Ilie [7], Marco [6], Matei [6], Ignat [6], Filip [5], Crăciun [4], Pavel [4], Maxim [4], Gavril [3], Sava [2], Grigore [2], Dimitrie [1], Constantin [1], Martin [1], Antonie [1], respectiv, în Țara Românească: Ioan [25], Petru [25], Mihail [22], Dimitrie [16], Teodor [15], Cristian [12], Cârstea [11], Ștefan [11], Nicolae [12], Gheorghe [8], Constantin [4], Simeon [3], Andrei [3], Grigore [2], Luca [2], Pavel [2], Sava [2], Antonie [1], Alexandru [1]. Se constată circulația acelorași prenume religioase în ambele provincii istorice, ceea ce dovedește unitatea inventarului onomastic creștin românesc. Dacă se ține seama de volumul dublu al atestărilor din Moldova, observăm că, în ambele arii, numele Ioan, Petru, Mihail, Teodor au o largă răspândire, iar Maxim, Grigore, Pavel, Gavril, Sava, Martin au frecvențe reduse. Diferențe de frecvență în favoarea uneia dintre ariile onomastice [Moldova / Țara Românească] se observă la nume ca Luca [19/2], Alexandru [9/2], Andrei [9 /3], Dimitrie [1 /16]. Prezențe exclusive, cu frecvențe ridicate, în repertoriul onomastic înregistrat în Moldova sunt nume ca Toma [19], Lazăr [10], Manoil [9], Ilie [7], Marco [6], Matei [6], Ignat [6], Filip [5], Maxim [4], Gavril [3], Martin [1], iar în Țara Românească, Cristian [12], Cârstea [11], Simeon [3]. Situația se explică poate prin lacunele documentare ale epocii, întrucât înregistrările de mai târziu le consemnează ca forme distribuite în ambele zone.

Unele dintre prenume apar în forma unică oficializată de calendarul ortodox (invarianta onomastică): Alexandru, Andrei, Antonie, Luca, Pavel, Sava, Ștefan. Cele mai multe, însă, prezintă, pe lângă forma calendaristică, și variante populare specific românești, Astfel, în Moldova apar forme ca Ion [64] pentru Ioan, Giurgiu [47], Giurgea [8], Ghiorghi [2], Jurja [1] pentru Gheorghe; Lazor [10] pentru Lazăr, Vasâle [1], Vasilie [1] pentru Vasile, Neculai [6], Nicoară [5], Necoară [3], Nicola [3], Nicula [3], Niculae [1], Nicolai [1] pentru Nicolae, Pătru [4] pentru Petru; Indrea [1] pentru Andrei, Gavrilă [1], Gavriil [1] pentru Gavril. Formele populare înregistrate în Ţara Românească sunt identice cu cele din Moldova: Ion [11], Pătru [12], Dimitru [9], Nicula [7], Gherghe [4], Petre [3], Nicola [3]. Unele nume moldovenești: Tador [19], Toader [14], Toder [4], Todor [2], Tudor [1], Jula [2], Julea [1], Giulă [1], Giulea [1], Iulie [1], respectiv, muntenești: Cârstiian [12], Tudor [9], Costantin [4] sunt notate exclusiv în varianta lor populară.

Numelor calendaristice (hagiografice și martirologice), preponderente în inventarul religios medieval, li se adaugă numele biblice, mai numeroase în Moldova: Isaia / Isaiu [8], David [7], Iachim [6], Ieremia [3], Iosif / Osif [3], Aaron / Aron [2], Avram [3], Iacob [2], Isac [2], Moise/ Moişă [2], Solomon [2] (Gonţa 1995).

3.1.2. În secolul 16, în ambele provincii istorice se constată că inventarul numelor primare religioase a rămas stabil în ceea ce privește formele alcătuitoare, dar numărul atestărilor crește, sugerând o amplificare a uzului lor în denominația personală. Seria prenumelor masculine muntenești cuprinde 22 de invariante calendaristice moldovenești, respectiv, 21, muntenești, diversificate în numeroase diverse variante populare mai răspîndite și, uneori, mai productive, a căror ierarhie de frecvență relativă este 
următoarea în Moldova: Ioan (138), Teodor (Toader, Tudor) (129), Gavri(i)l (97), Ștefan (Stefan) (95), Toma (92), Gheorghe (Gheorghie) (86), Mihail (79), Dumitru (Dimitrie) (69), Luca (56), Maxim (56), Lazăr (Lazor, Lazur) (40), Matei (Maftei) (33), Andrei (25), Petru (Pătru) (22), Ilie (22), Grigore (Gligore) (20), Nicolae (Nicoară, Niculae, Neculai) (18), Antonie (Anton) (14), Pavel (Pavăl) (11), Alexandru (10 (Gonța 1995), respectiv, în Țara Românească: Dimitrie [197]: Dumitru [192]; Petru [106]; T[h]eodor [99]: Tudor [63, Toader [16], Io[a]n [180; Mihail [89]; Nicolae [54; Gheorghe [48]; Vasile [48; Ștefan [38]; Toma [28]; Constantin [23]: Costandin [23]; Andrei [15]; Ilie [14]; Iacob [10]: Iacov [8]; Alexandru [9]; Antonie [3]; Luca [3]; Pavel [3]; Gavril [2] Gavrilă [1] (DRHB II:491-555, III:368-418, IV:359-403, V:380-425, VI:316-359, VII:354-407, VIII:554-611). Prima poziție în ierarhia de frecvență a numelor de botez moldovenești revine numelui Ioan, iar, în onomastica muntenească, numelui Dumitru, cu atestări medii, deci mai puțin folosit, în Moldova. Numele de botez Gavri(i)l se situează pe locul al doilea în Moldova și pe ultimul loc în Țara Românească.

3.1.3. În secolul 17 , uzul numele religioase ia amploare, avînd în vedere numărul sporit al înregistrărilor pentru fiecare formă. În Moldova, între anii 1637 și 1638, aparițiile numelor religioase confirmă uzul preferențial al unor forme onomastice din seria denominației religioase: Teodor (Toader, Tador, Todor, Tudor) (147), Vasile (Vasilie, Vasâle) (134), Ioan (Ion) (103), Gheorghe (Ghiorghe, Ghiorghi, Ghiorghie, Giorgiu, Giordzu, Giurgiu) (94), Ștefan (Stefan) (72), Gavri(i)l (63), Dumitru (Dimitrie) (58), Constantin (Constandin, Costandin) (50), Simion (49), Grigore (Grigor(i)e), Gligor(i)e) (48), Nicolae (Necoară, Nicoară, Necolai, Neculaie) (39), Toma (26), Pavel (22), Petre (Pătru) (21), Ilie (20), Matei (Maftei) (20), Crăciun (18), Lazăr (Lazor) (18), Sava (18), Ignat (17), Mihail (Mihai) (17), Roman (14) (DRHA XXIV:498-606). În Țara Românească, în aceeași perioadă, se remarcă o tendință de creștere similară a circulației unor nume, ilustrată statistic de atestările numelor calendaristice dintr-un singur an (1647): Dimitrie [87]: Dumitru [85]; Ioan [73]: Ion [63], Petru [65]:; Gheorghe [52; T[h]eodor [50]: Tudor [32],; Vasile [26]:; Mihail [22]:Mihaiu [12]; Constantin [19; Andrei [15]; Ștefan [15]; Toma [11]; Anton[ie] [9]; Ilie [5]: Ilie [3], Elie [1]; Pavel [2] (DRHB. XXXII: 333-400). Cu frecvențe moderate, apar nume calendaristice sporadic sau deloc înregistrate anterior: Simeon, Sava, Damian, Hristodor, Spiridon, Filip, Iachim, care vor schimba temporar, prin diversificare, inventarul onomastic. De asemenea, sunt înregistrate forme onomastice necalendaristice, dar legate de viața religioasă, puțin răspândite în secolul 16, între care se disting nume delexicale de origine grecolatină cu semnificații creștine: Anghel „înger” [5], Apostol [1], cu tendința de creștere a frecvențelor în perioada următoare: Anghel [10], Apostol [3] a.1628-1629 [DRHB XXIII:671-770], respectiv, Anghel [18], Apostol [3] a.1647 [DRHB XXXII:335].

Numele biblice sunt în creștere, ajungând, până în secolul 17, la un număr mai mare de apariții anuale decât totalul atestărilor anterioare, mai ales în Moldova (Gonța 1995): Avra[a]m [33], Zahari[i]a [19], David [16], Moise [Moisi] [15], Solomon [7], Iov, Iovu [5]. În această arie, apar, din aceeași sursă, nume noi, atribuite relativ frecvent: 
Isac [23], Saul [14], Adam [6], Isaia [5], Aaron, Aron [3] [DRHA XXIV:498-606]. Comparativ, atestările numelor muntenești de inspirație biblică sunt mai puțin numeroase: David [11], Avra[a]m [10], Moise [3], I[o]vu [2] [DRHB XXIII:671-770, XXXII:333-400].

\subsection{Numele primare religioase feminine}

3.2.1. În secolul 15 , prenumele feminine religioase alcătuiesc o serie mai restrânsă, cu un număr redus de forme de bază, moldovenești (9) (Gonța 1995) și muntenești (6) (DRHB I: 529-586). Apariția numelor în documente, care indică frecvența relativă pentru perioada istorică respectivă este relativ rară, atât în Moldova: Marena/ Mărena [6], Maria [4], Marina [4],Marta [3], Anna/Ana [2], Anastasia [1], Ileana [1], Mara [1], Măgdălina [1], cât și în Țara Românească: Maria [5] Anca [4] < Ana, Marina [2], Catalina < Ecaterina [1], Elena [1], Tudora [1]. Ca și în cazul numelor primare masculine, unele forme populare sunt mai răspândite decât invariantele fixate calendaristic. $\mathrm{Nu}$ toate numele feminine religioase reprezintă forme calendaristice propriuzise. Formarea numelor feminine de la nume calendaristice masculine, prin derivare moțională specifică cu sufixul onomastic -a: Cărstiiana $[1]<$ Cârstiian, Constantina < Constantin este încă la început în ambele arii istorice.

3.2.2. În secolul 16, structura inventarului de nume religioase destinate denominației feminine primare este, însă, aceeași în ambele zone, Moldova și Țara Românească, cu deosebirea că formele feminine religioase moldovenești: Ana (96), Maria (64), Tudora (< Theodora) (47), Elena (Elina, Ilina, Ileana) (43), Magda (< Magdalena) (42), Măgdălina (< Magdalena) (35), Cristina (32), Varvara (31), Teodosia (27), Irina (25), Marta (22), Paraschiva (2) (Reguș 1999: 73-75) predomină în concurența cu cele muntenești: Maria [51], Elena [Elina, Ilina, Ileana] [13], Irina [11], Ana [10], Paraschiva [6], Magdalina [Măgdălina] [4], Marta [3], în ceea ce privește rangurile de frecvență. Observația este valabilă și pentru numele de botez feminine, aparent calendaristice, formate prin derivare moțională de la un nume masculin: Anghelina (60) (<Anghel), Tudora (47) $(<$ Tudor < Theodor) sau forme exclusive: Teodosia (27) (< Teodosie), Sofroni(i)a (14) (< Sofronie) (Reguș 1999: 73-75) cu circulație mai largă în zona moldovenească.

3.2.3. Secolul 17 nu aduce mari modificări inventarului de bază al numelor de botez feminine, dar amplifică sau reduce circulația lor, consolidând sau slăbind tradiția formelor de bază. În același timp se constată tendința de îmbogățire a repertoriului onomastic general prin introducerea unor nume noi, unele cu existență efemeră, mai ales în Moldova: Agafia, Agahia (4), Palaghia, Pelaghia (4), Marta (2), Anesia, Anisiia (2), Elisafta (< Elisabeta) (1), Olena (1) (< Elena) (Gonța 1995).

\section{Numele primare laice}

Numele românești de factură laică alcătuiesc un repertoriu onomastic paralel cu cel religios, în a cărui structură se disting ca importanță, prin număr și frecvență, împrumuturile vechi de origine slavă, precum și nume nou create pe baza vocabularului 
românesc. La acestea se adaugă, cu apariție sporadică și nesemnificativă, împrumuturi de nume maghiare, lituaniene, poloneze sau germane, pe care nu le vom analiza în lucrarea de față. Numele de botez / prenumele provenite de la forme lexicale românești alcătuiesc o serie mai puțin numeroasă în comparație cu seria numelor religioase și cu cea a împrumuturilor laice, dar reprezentativă pentru creativitatea sistemului onomastic autohton. Prin modul lor de formare, numele de botez / prenumele cu bază lexicală ar trebui să alcătuiască un repertoriu mobil, deschis, în cadrul căruia cuvinte din vocabularul limbii române se fixează ca nume proprii de persoană, modificându-și funcția și forma.

\subsection{Numele primare laice masculine}

\subsubsection{Imprumuturile slave}

4.1.1.1. Numele masculine de origine slavă, documentate în secolul 15, în număr de 22 în Moldova (DRHA I 434-510, II 462-533) și 37 în Țara Românească (DRHB I 529-586), cele mai multe atestate anterior, sunt printre cele mai frecvente în inventarul antroponimic general. În ambele arii istorice, pe primele locuri se situează numele simple, rezultate din trunchierea compuselor bitematice slave de origine. Observăm, însă, că, spre deosebire de numele religioase, atestările numelor slave de acest fel din inventarul muntenesc depășesc pe cele din repertoriul moldovenesc. Astfel, în Țara Românească, ierarhia împrumuturilor slave după numărul atestărilor este următoarea: Radu [97] < Radomir, Radoslav etc.; Stan [59] < Stanomir, Stanislav etc.; Vlad [38] < Vladimir, Vladislav etc.; Neagu [15] < Neagomir, Neagoslav etc.; Brat/Bratul [10] < Bratomir, Bratoslav etc.; Drag/Dragul [5] < Dragomir, Dragoslav etc.; Bran [4] < Branimir, Branislav etc.; Dobre/ Dobrul [4] < Dobromir, Dobroslav etc. Ocurențe ridicate și medii se înregistrează și în cazul prenumelor provenite din forme slave derivate, în general, sud-slave (bulgărești sau sârbești), cu sufixul -čo: Stanciu [58], Danciu [12]; -ca/-co: Stoica [57], Mircea [14], Vâlcea/Vâlcu [11], Vlaicu / Vlaico [11], Voico/Voicu [11]; -oe: Neagoe [18], Stroe [7], Stoe/ Stoia [4], Dobrotă [3], Dragotă [3] etc. Alături de numele slave simple și derivate, formele slave compuse sunt frecvente în onomastica perioadei, înregistrându-se atât nume care au continuitate în sistemul românesc: Dragomir [37], Radomir [5], Dobromir [4], Tatomir [3], Neagomir [1], Vladimir [1], Vladislav [6], Stanislav/Stănislav [5], Radoslav [3], Dragoslav [2], Branislav [1], Voislav [1], cât și împrumuturi efemere: Draghislav [1], Razimir [1], Strațimir [1]. In Moldova, numărul de apariții documentare ale împrumuturilor slave este mai mic, deși volumul de documente existent este aproape dublu. Numele slave simple prezintă următoarele ocurențe: Stan [38], Vlad [20], Radu[l] [17], Brat/Bratu[l] [10], Neagu[l] [7], Dobru[l] [1], iar cele derivate prezintă aceeași scădere semnificativă: Stanciu[l] [18], Danciu[1] [15], Mircea [8], Vâlce/Vâlcu[l] [7], Stroe [5], Neagoe [4], Vlaicu[l] [3], Voico/Voicu[l] [3], Stoica [1]. Unele prenume muntenești de origine slavă nu sunt înregistrate în Moldova: Drag/Dragu(l), Bran, Stoe/ Stoia, Preda, iar nume moldovenești de origine slavă exclusive nu există. Cantitatea și frecvența împrumuturilor slave 
compuse este inferioară formelor similare muntenești In afara prenumelor Dragomir [15 ] și Stanislav/Stănislav [1], celelalte nume slave compuse: Branislav, Dragoslav, Dobromir, Neagomir, Radomir, Radoslav, Vladislav nu mai apar în documentele din Moldova. In schimb, izolat, se înregistrează forme noi ca: Aldomir, Balomir, Cernislav, Dragosin, Stanimir.

4.1.1.2. În secolul 16, în Țara Românească (DRHB II:491-555, III:368-418, IV:359-403, V:380-425, VI:316-359, VII:354-407, VIII:554-611) se preferă relativ aceleași nume care au circulat în secolul anterior, dar numărul ocurențelor este foarte ridicat: Radu(l) [564], Stan [457], Stanciu(l) [346], Vlad(ul) [303], Stoica [285], Dragomir [238], Neagoe [164], Dan [133], Voico/Voicu(l) [102], Neag(ul) [98], Drăghici [93], Vlaicu(l) [82], Staico [71], Pârve/Părvu(l) [67], Mircea [58], Bratu(l) [55], Stoian [51], [50], Vâlcu(l) [48], Stănilă [45], Vintilă [42], Drăgan [39], Preda [35], Danciu(l) [33], Drăgoi [31], Dobre/ Dobru(l) [30], Dragotă [28], Stoia [27], Dobrotă [22], Radomir [20], Dobromir [19], Neacşu(l) [18]. Acestora li se adaugă noi atestări ale unor nume de aceeași origine, cu circulație mai restrânsă: Vâlsan [7], Pravăț [3], sau cu apariții izolate Miru [1]. Primele șase nume slave au atestări mult mai numeroase decât cele mai răspândite nume calendaristice din aceeași perioadă, primele două având un număr triplu sau dublu de înregistrări faţă de primul clasat din seria numelor religioase. În acelaşi timp, în Moldova [Gonţa 1995] se constată o scădere semnificativă a numărului de atestări ale prenumelor masculine de origine slavă, mai ales dacă avem în vedere amploarea documentației moldovenești. Ierarhizarea acestor nume, după frecvența mențiunilor documentare, arată diferențe între inventarele onomastice ale celor două provincii istorice: Stan [32], Neag(ul) [24], Stanciu(l) [20], Vlad [19], Mircea [18], Neacșu(l) [18], Radu(l) [16], Danciu(l) [15], Bogdan [14], Dan [10], Brat(ul) [10], Vlaicu(l) [10], Vâlce/Vâlcu(l) [8], Stroe [5/7], Neagoe [8] Pârve/ Părvu(l) [5], Stoica [5], Vâlcan [5], Dobre/ Dobru(l) [3], Preda [3], Voico [3], Aldimir [2], Dobromir [1], Stănislav [1].

4.1.1.3. În secolul 17, poziția numelor primare masculine de origine slavă se consolidează în Țara Românească, în timp ce se menține tendința de reducere a repertoriului acestor nume, precum și de scădere a frecvențelor în Moldova. Această contradicție este ilustrată de frecvențele stabilite în intervalul (1630-1632) în aria muntenească: Radu(1] [183], Stan [141], Stoica [115], Stanciu(l) [96], Dragomir [75], Vlad(ul) [71], Neagoe [55], Preda [43], Voico [40], Neag(ul) [41], Drăghici [28], Stroe [27], Nedelco [25], Pârvu(l) [25], Stoian [24], Danciu(l) [20], Staico [19], Drăgan [18], Brat(ul) [16], Dobre [16], Drag(ul) [15], Vlaicu(l) [16] etc. (DRHB XXIII:671-770), respectiv, de cele constatate în aria moldovenească la o dată apropiată: Radu(l) [10], Bogdan [5], Danciu(l) [4], Neagoe [4], Brat(ul) [2], Stan [2], Dobre[a] [1], Neag(ul) [1], Stanciu(l) [1], Stoia [1], Stancu [1] etc., precum și de absența unor nume atestate în secolul anterior, precum Dragomir, Stroe, Pârvul, Voico etc . Numele slave nou înregistrate în Moldova au apariții izolate: Zlat [3], Borcea [2], Balaci [1], Bran [1], Dobroslav [1], Nedelco [1], Negomir [1], Pravăț [1], Prodan [1], Sin [1] etc. [DRHA XXIV:498-606]. 


\subsubsection{Prenumele laice masculine - creații româneşti}

4.1.2.1. Numele primare mirene masculine, create pe baza unor elemente lexicale ale limbii române, sunt, în secolul 15, un model onomastic mai slab din punctul de vedere al cantității și al frecvenței. Prenumele de acest fel, în număr de 10, au, în ambele arii, forme identice, asemănătoare ca număr de înregistrări: Bucur [3/5], Fătu [2/1], Grozav [1/1], Lupșa/Lupșe [1/1], Muşat [3/3] Puiul [1/1], Șerbu [3/3], cu excepția formelor cu frecvențe mai ridicate în Țara Românească: $M i c(u l)$ [21/11], Albu(l) [10/16] sau în Moldova: Badea [5/24]. Pe lângă aceste nume tradiționale, sunt înregistrate, în Moldova, prenume care nu se regăsesc în inventarul onomastic medieval muntenesc: Mândre(a) [5], Mălin [1], Zorea [1].

4.1.2.2. În secolul 16, numărul formelor onomastice primare delexicale crește, înregistrându-se 25 de nume de botez/prenume ${ }^{3}$ provenite de la nume comune ${ }^{4}$ în Țara Românească. Cele mai multe dintre acestea [21 de nume] au atestări în secolele anterioare, dar, în această perioadă, își consolidează tradiția, printr-o circulație mai activă, indicată de un număr mult mai mare de apariții documentare: Badea [74], Albu(l) [73], Lupu(l) [89], S,erban [72], Micu(l) [65], Oprea [51], Muşat [42], Coman [38], Lepădat [26] Fătu(l) [20], Ursu(l) [14], Bucur [12], Lăudat [19], Șerbu(l) [11], Grozav [10], Florea [11]. Câteva nume de botez delexicale sunt menționate pentru întâia oară în prima jumătate a secolului 16: Puiu, Bărbăteiu, Lupeaiu, Păun [Păunul] [DRHB II:157, 182, 254]. Numărul numelor de botez de aceeași factură din Moldova este mai mic (18 nume), dar coincidența formelor este evidentă. Ceea ce deosebește seria de nume delexicale din Moldova este circulația lor, indicată de numărul mai mic de atestări: Lupu(l) [40], Mic(ul) [24], Ursu(l) [19], Fătu(l)[16], Florea [12], Albu(l) [11], Oprea [8], Ban(ul) [7], Șerban [6], Fârtat [3], Fratea [3], Lepădat [3], Bucur [2], Mușat [2], Șerb [1 [Gonța 1995]. Singura excepție o constituie prenumele Grozav, care în aria muntenească apare mai rar [11], decât în cea moldovenească [60].

4.1.2.3. În secolul 17, frecvențele unor nume delexicale muntenești sunt în creștere: Oprea [140], Badea [40], Alb [ul] [26], Mușat [19], Coman [18], ca și a celor moldovenești: Lupu[1] [37], Ursu[1] [25], Florea [13]. În același timp, forme muntenești: Grozav [6], Florea [6], Ban[ul] [5], Grozea [5], Fratea [5], Lăudat [4], Cornea [3], Bucur [2], Bunu[1] [2], Fârtat [2], Trandafir [2], Badiul [2], Grozav [1], Serbu[1] [1] etc. [DRHB XXIII:671-770]. respectiv, moldovenești: Grozav [6], Mic(ul) [3], Fătu(l) [1], Oprea [3], Ban [ul] [1], Șerban [1], Bucur [2], Muşat [2], Barbu [1], Fârtat [1], Șerb [1] (DRHA XXIV:498-606), manifestă o relativă scădere. Pe lângă numele tradiționale comune, în Moldova sunt atestate în secolul al XVI-lea forme noi ca Mândru, Mândre / Mândrea [8], Murguleț [6], Murg [1].

3 Dificultatea de a departaja numele de botez/prenumele delexicale de supranumele individuale de aceeași origine impune luarea în considerație numai a formelor care apar în structura numelui dublu (mixt) sau cele care au dezvoltat o tradiție ca nume de botez.

$4 \mathrm{Nu}$ a fost luat în considerație numele destul de răspândit Barbu(l) (98), a cărui etimologie lexicală este nesigură. 


\subsection{Numele primare laice feminine}

\subsubsection{Imprumuturile slave}

4.2.1.1. În secolul 15, prenumele feminine de origine slavă alcătuiesc o serie denominativă mai restrânsă, cu destul de puține atestări, care include 13 forme muntenești: Stana [6], Stanca [6], Neaga [3], Rada [3], Neacșa [2], Staia [2], Vladaia [2], Voica [2], Boba [1], Calea [1], Dobra [1], Pârvana [1], Vişa [1] [DRHB I 529-586], și 7 moldovenești: Cerna [3], Chiajna [1], Grada [1], Neaga [1], Neagșa [1], Staia [1], Vișa [1]. Împrumuturile slave propriu-zise sunt rare în ambele arii, dar au forme diferite: Calea, Staia, Vișa, în Țara Românească, Cerna, Chiajna, Grada, în Moldova. Cele mai multe nume feminine din această serie sunt derivate românești de la prenume slave masculine, cu sufixe de feminizare diferite: - a: Stana, Stanca, Neaga, Rada, Neacșa etc. și -ia: Vlad/Vladaia etc.

4.2.1.2. În secolul 16, numele primare laice feminine de origine slavă prezintă un inventar mai numeros de 125 de forme, reprezentând împrumuturi slave vechi și neoslave. Circulația acestor nume este foarte diferită. În Moldova, se constituie un nucleu de 21 de nume feminine cu frecvențe ridicate: Neacșa [Neagșa] [81], Stana [68], Neaga [67], Stanca [54], Dobra [49], Rada [44], Vișa [33], Vlădae [21], Velica [14], Slavna [Slamna] [13], Voica [11], Stoica [10] sau cu frecvențe medii: Buica [9], Neagolea [9], Dragolea [8], Drăgana [8], Stoiana [6], Vlada [6], Dragomira [5], Moma [5] [Reguș 1999:77-78]. În același inventar, 42 de nume au apariții sporadice sau izolate în documente: Malea, Nedealca, Slava, Vișana, Zlata [3]; Bisa, Cheajna [Cneajna], Mira, Sănislava, Sina, Stănae [2], Băla, Brănae, Bunaica, Dobraia, Dobrana, Dobreașa, Dobrina, Dragaia, Drăgaica, Drăghina, Dragosina, Mirana, Nedelea, Pârva, Pârvana, Preda, Prodana, Raica, Rădae, Răduca, Răduța, Sâmbotina, Slavița, Staia, Vâlsana, Vlăduca, Voichița, Voina, Voislava, Zlatca [1] etc. [Reguș 1999:125-202]. În Țara Românească, repertoriul principal de nume feminine de origine slavă este similar celui din Moldova, ca număr și frecvențe. Cele mai multe nume continuă vechi forme atestate în secolul anterior, la care se adaugă înregistrări noi: Velica, Vlada, Slavna, Stoiana, Stoica, Neagolea, Moma, Vilae, Buica, Dragomira [DRHB VII 236]. Majoritatea numelor perechi cu nume masculine de la care s-au format prin derivare onomastică moțională cu sufixele Dragolea [< Dragole], Dragomira [< Dragomir]; Drăgana [<Drăgan]; Neaga $[<$ Neag[ul]], Rada [<Rad[ul]], Stana [<Stan] etc., [-ae] Brănae [< Bran], Rădae $[<$ Rad[ul]], Stănae [<Stan]; Vlădae [< Vlad] etc.

4.2.1.3. Comparativ cu secolul 16 , care atestă o mare varietate de forme onomastice feminine de origine slavă, secolul 17 se caracterizează printr-un număr mai mic de mențiuni documentare ale unor asemenea nume, fapt explicabil, pe de o parte, prin documentarea parțială a onomasticii din Țara Românească în a doua jumătate a acestui secol față de posibilitatea documentării aproape exhaustive a secolului 16, iar, pe de altă parte, prin realitatea onomastică a epocii în care numele feminine de acest tip se reduc treptat până la dispariție în secolul 18. Inventarul numelor laice feminine de origine slavă din antroponimia muntenească a secolului 17 [DRHB XXII:711-798, 
XXIII:671-770, XXXII:333-400] cuprinde, cu câteva excepții, doar 15 forme care le continuă pe cele cu frecvențe ridicate în perioada anterioară, toate formate ca derivate moționale de la numele masculine, în cadrul unor perechi denominative de gen. Circulația lor se păstrează la aceleași cote de frecvență sau chiar puțin mai ridicate: Stana [64], Neacşa [58], Neaga [57], Stanca [44], Voica [34], Rada [29], Vişa [17], Dobra [16], Velica [10], Vlădae [6], Stoica [10], Stoiana [10], Vlada [7], Dragomira [3], Dana [3] etc. Reducerea inventarului acestora de la 94 de forme identificate în secolul 16 la aproximativ 21 de nume de botez de același fel inventariate în secolul 15 exprimă tendința de marginalizare a împrumuturilor laice slave, urmată de ieșirea lor treptată din uz, care nu caracterizează, în egală măsură, numele de botez masculine corespunzătoare.

\subsubsection{Prenumele laice feminine - creații româneşti}

4.2.2.1. Seria numelor de botez / prenumele feminine laice delexicale este destul de redusă în secolul 15, în special în aria muntenească, în care sunt atestate izolat doar 2 forme: Mica [2], Buna [1]. Prenumele feminine cu bază lexicală din Moldova sunt mai frecvente, prezentând forme rare ca Ghinda [2], Luna [1], Motruna [1], Negrita [1], precum și 2 forme de inspirație etnică: Armanca, Rusca, nelegate de etnia purtătoarei numelui.

4.2.2.2. Repertoriul numelor feminine de acest tip se îmbogățește semnificativ în secolul 16, ajungând în Moldova, la 28 de forme, mai numeroase decât cele din seria masculină corespunzătoare: Mușa (33) (< Muşata), Sora (22), Buna (6), Comana (5), Dafina (4), Negrita (3), Sor(i)ca (3), Samfira (3), Armeanca (2), Țigănușa (2), Ursa (1), Caprina (1), Floare (1), Brândușa (1), Sasca (1), Lupa (1), Alba (1) 78, Barba (1), Fecio(a)ra (1), Greaca (1), Mierla, Păuna (1), Șarba (1), Șărbana (1), Șerbaia (1), Ungura (1) (Reguș 1999:82-87). Cele mai multe nume feminine reprezintă, de fapt, derivate ale unor nume de botez masculine cu sufixele onomastice moționale -a: Alba $<$ Albu, Barba $<$ Barbu, Comana < Coman, Lupa < Lupu, Mușata < Mușat, Păuna < Păun, Șarba $<$ Șerbu, Șărbana < Șărban, Ursa < Ursu etc., precum și -(o)aia: Șerbaia < Șerb (u) etc.

4.2.2.3. Procesul de formare a numelor primare de la apelative a avut o dinamică caracteristică. Deși numărul lor este destul de mic în perioada de început, se consideră că aceste nume au constituit un sistem bogat, preexistent împrumuturilor slave, care, împreună cu numele religioase, le-au eliminat treptat în decursul înnoirii fondului antroponimic (Reguș 1999: 88). Cele mai multe dintre aceste prenume au avut o existență efemeră în sistemul onomastic românesc, dispărând chiar din secolul 18.

5. Rezultatele analizei comparative a numelor primare religioase și laice înregistrate în documentele epocii medievale pun în lumină următoarele aspecte:

- constituirea unor tradiții onomastice comune, precum și manifestarea unor tendințe unitare legate de atribuirea numelor, de structura inventarului de forme;

- formarea un subsistem denominativ unitar, cu trăsături funcționale și formale comune, cu inventar similar în ariile românești;

- prezența unor diferențe de ordin cantitativ și de frecvență a numelor în 
repertoriul fiecărei arii, explicabile, obiectiv, prin condiții istorico-culturale distincte și, subiectiv, prin preferințele denominative diverse.

\section{Bibliografie}

Bălan-Mihailovici, A. 2002. Dicţionar onomastic creştin. Bucureşti: Editura Minerva.

Constantinescu, N. A. 1963. Diç̧̧ionarul onomastic românesc. Bucureşti: Editura Academiei.

Gonța, Al. I. 1995. Documente privind istoria României. A.Moldova (veacurile XIV-XVII (13841625). Indicele numelor de persoane. Bucureşti: Editura Academiei Române.

Paşca, Şt. 1936. Nume de persoane şi nume de animale in Țara Oltului. Bucureşti: Imprimeria națională.

Reguş, A. şi C. Reguş. 1999. Nume de femei in vechi acte istorice (sec. XIV-XVI). Bucureşti: Editura Mustang.

Tomescu, D.. 2001. Numele de persoană la români. Perspectivă istorică. Bucureşti: Editura Univers Enciclopedic.

\section{Surse}

DRHA I = Cihodaru, C. et al. (ed.). 1975. Documenta Romaniae Historica, seria A. Moldova. Vol. I (1384-1448). București: Editura Academiei.

DRHA II = Şimanschi, L. et al. (ed.). 1976. Documenta Romaniae Historica, seria A. Moldova. Vol. I (1449-1486). Bucureşti: Editura Academiei.

DRHA XXIV = Cihodaru, C. şi I. Caproşu. 1998. Documenta Romaniae Historica, seria A. Moldova. Vol. XXIV (1637-1638). Bucureşti: Editura Academiei Române.

DRHB I = Oțetea, A. et al. 1966. Documenta Romaniae Historica, seria B. Țara Românească. Vol. I (1247-1500). Bucureşti: Editura Academiei.

DRHB II = Ștefănescu, Ș. şi O. Diaconescu (ed.). 1972. Documenta Romaniae Historica. Seria B. Țara Românească. Vol. II (1501-1525). București: Editura Academiei.

DRHB III = Mioc, D. (ed.). 1975. Documenta Romaniae Historica. Seria B. Țara Românească. Vol. III (1526-1535). București: Editura Academiei.

DRHB IV = Mioc, D. (ed.). 1981. Documenta Romaniae Historica. Seria B. Ţara Românească. Vol. IV (1536-1550). București: Editura Academiei.

DRHB V = Mioc, D. (ed.). 1983. Documenta Romaniae Historica. Seria B. Țara Românească. Vol. V (1551-1565). București: Editura Academiei.

DRHB VI = Ștefănescu, Ș. şi O. Diaconescu (ed.). 1985. Documenta Romaniae Historica. Seria B. Țara Românească. Vol. VI (1566-1570). București: Editura Academiei.

DRHB VII = Ștefănescu, Ș. şi O. Diaconescu (ed.). 1988. Documenta Romaniae Historica. Seria B. Țara Românească. Vol. VII (1571-1575). București. Editura Academiei.

DRHB VIII = Mioc, D. și Constantinescu, I. (ed.). 1996. Documenta Romaniae Historica. Seria B. Țara Românească. Vol. VIII (1576-1580). București: Editura Academiei Române.

DRHB XXIII = Mioc, D. (ed.).1969. Documenta Romaniae Historica. Seria B. Țara Românească. Vol. XXIII (1630-1632). București. Editura Academiei.

DRHB XXV = Mioc, D. et al. (ed.). 1985. Documenta Romaniae Historica. Seria B. Țara Românească. Vol. XXV (1635-1636). București. Editura Academiei.

DRHB XXXII = Barbu, V. şi Gh. Lazăr (ed.). 2001. Documenta Romaniae Historica. Seria B. Ţara Românească. Vol. XXXII (1647). București. Editura Academiei Române. 